\title{
DESIGN PROCEDURE OF AN ELECTROHYDRAULIC DRIVE
}

\author{
Srishti Sharma ${ }^{1}$, Ramesh R. Lekurwale ${ }^{2}$, Amith Masade ${ }^{3}$ \\ ${ }^{I}$ Department of Mechanical Engineering, K. J Somaiya College of Engineering, Mumbai, Maharashtra, India \\ ${ }^{2}$ Department of Mechanical Engineering, K. J Somaiya College of Engineering, Mumbai, Maharashtra, India \\ ${ }^{3}$ Manager, Product \& Technology Development Centre, Heavy Engineering, Larsen \& Toubro Ltd, Mumbai, \\ Maharashtra, India
}

\begin{abstract}
Aerodynamicists use wind tunnel to test models as well as for proposed aircraft components and engines. In order to keep these models fixed in place for testing, ground based equipment is essential. Electrohydraulic drives form the back bone of such type of mechanism which requires continuous motion for life time operations with controlled motion for start stop and bi-directional motion mechanisms. Focus of this paper is on systematic approach for optimal designing of a typical electrohydraulic drive that will provide roll motion to the testing model with emphasis on reliability of the system. This paper further highlights the design, selection, testing and qualification procedures of different elements of the drive and the electrohydraulic drive assembly as a whole.
\end{abstract}

Keywords - Design, Develop, Electrohydraulic roll drive, Spindle.

\section{INTRODUCTION}

The modern technology and ever demanding need for the design of newer means to test models in wind tunnel has led to significant developments in the area. With the increase in demand of large appendage deployment and several tracking mechanisms; the application of electrohydraulic drives has increased exponentially. Hydraulic servo systems can generate high forces also exhibit rapid responses, and have a high power-to-weight ratio compared to other technologies. On the other hand, they have a significant nonlinear behavior due to the nonlinear flow/pressure characteristics, oil compressibility, time varying behavior, nonlinear transmission effects, flow forces acting on spool and friction, which is not only largely uncertain but is greatly influenced by external load disturbances. Hydraulic systems are mechanically "stiffer", resulting in higher machine frame resonant frequencies for a given power, high loop gain and improved dynamic performance. They also have the benefit of being self-cooled since the driving fluid effectively acts as a cooling medium carrying heat away from the actuator and flow control components [1]. Quality and reliability aspects are of prime importance at each stage [2]. Every component whether designed or selected is checked for various aspects related to the requirement and chosen such that the complete design is compact and accurate. The roll drive is very important from aerodynamic testing point of view as well as to hold the model in correct and steady position for testing at various roll ranges.

\section{PROBLEM DEFINITION}

The paper discusses design of a roll drive that would roll at a specific rate and for a specific roll range by overcoming the aerodynamic forces and moments acting on the roll drive. In order to design a roll drive the various mechanical and electrical devices conceptualized are the sting, pod, motor/actuators, bearings, feedback devices, hydraulic cylinders, servo valves, seals, retainers, bolts, etc. Motors, Bearings, feedback devices, valves, cylinders, seals and bolts are the standard parts and were studied in depth with the various classifications and types to choose the best as per our requirement. There is a five axis manipulator with Horizontal, Vertical, Yaw, Pitch \& Roll motions. The aerodynamic loads and moments act on the face of the roll drive and can be seen as below:

Table 1: Aerodynamic Forces and Moments acting on the Roll drive.

\begin{tabular}{|l|l|l|}
\hline Forces/Moments & Symbol & Unit \\
\hline Normal Force & $\mathrm{F}_{\mathrm{n}}$ & $\mathrm{N}$ \\
\hline Axial Force & $\mathrm{F}_{\mathrm{a}}$ & $\mathrm{N}$ \\
\hline Side Force & $\mathrm{F}_{\mathrm{s}}$ & $\mathrm{N}$ \\
\hline Pitching Moment & $\mathrm{M}_{\mathrm{p}}$ & $\mathrm{Nm}$ \\
\hline Yawing Moment & $\mathrm{M}_{\mathrm{y}}$ & $\mathrm{Nm}$ \\
\hline Rolling Moment & $\mathrm{M}_{\mathrm{r}}$ & $\mathrm{Nm}$ \\
\hline
\end{tabular}

Accuracy of the roll required is \pm 0.05 degrees or better. The roll range is of $-90^{\circ}$ to $+90^{\circ}$, whereas the roll rate is $0-25$ $\mathrm{rad} / \mathrm{sec}$ at variable rate.

\section{DESIGN \& DEVELOPMENT}

\subsection{Motors/Actuators}

The very first system required to conceptualize the roll drive is a motor/actuator. There were three concepts that were realized to achieve this type of motion namely (a) Direct 
Electric drive (b) Gearbox with Electric Drive (c) Gearbox with Hydraulic Drive.

(a) Direct Electric Drive: There exist various electric drives but there are specifically three drives that are used for aerospace related applications [2] and can be listed as :

- Brush DC motors

- Brushless DC motors

- Stepper or Servo motors

Based on the comparison between the drives and advantages of the servo motor for the need of the application we choose the Servo Motor from make such as Moog or Rexroth to fulfill the space requirements, torque and size parameters.

(b) Gearbox with Electric Drive: The limitation with the direct drive is the bulkiness of the servo motor due to which a gearbox was conceptualized with a motor of lesser torque value such as Parker gearbox \& motor kit, or any other to reduce the size of the motor and fulfill the torque characteristics.

(c) Gearbox with Hydraulic Drive: an alternative for an electric drive is a hydraulic drive option which is explored with a planetary helical gearbox. One may choose Dan Foss hydraulic motor with a Parker Gearbox to fulfill the functional requirements.

To choose the best available option for the drive a decision matrix was made on the basis of few engineering parameters [3] and can be seen as in the table below:

Table 2: Decision Matrix

\begin{tabular}{|l|l|l|l|}
\hline PARAMETERS & $\begin{array}{l}\text { DIRECT } \\
\text { ELECTRI } \\
\text { C DRIVE }\end{array}$ & $\begin{array}{l}\text { ELECTRI } \\
\text { WITH } \\
\text { GEARBO } \\
\text { X }\end{array}$ & $\begin{array}{l}\text { HYDRAULI } \\
\text { WITH DRIVE } \\
\text { GEARBOX }\end{array}$ \\
\hline $\begin{array}{l}\text { FUNCTIONAL } \\
\text { REQUIREMEN } \\
\text { T }\end{array}$ & 2 & 2 & 2 \\
\hline $\begin{array}{l}\text { OPERATIONA } \\
\text { L SAFETY }\end{array}$ & 2 & 2 & 2 \\
\hline $\begin{array}{l}\text { EASE OF } \\
\text { ASSEMBLY/ } \\
\text { DISASSEMBL } \\
\text { Y }\end{array}$ & 2 & 1 & 0 \\
\hline RELIABLITY & 2 & 2 & 2 \\
\hline FEASIBLITY & 2 & 2 & 2 \\
\hline ACCURACY & 2 & 1 & 1 \\
\hline $\begin{array}{l}\text { PROCUREMEN } \\
\text { T }\end{array}$ & 0 & 1 & 2 \\
\hline COST & 0 & 1 & 1 \\
\hline AESTHETICS & 2 & 1 & 0 \\
\hline WEIGHT & 0 & 1 & 2 \\
\hline $\begin{array}{l}\text { SPACE } \\
\text { REQUIRED }\end{array}$ & 0 & 1 & 1 \\
\hline
\end{tabular}

\begin{tabular}{|l|l|l|l|}
\hline $\begin{array}{l}\text { OIL LEAK IN } \\
\text { VACUUM }\end{array}$ & 2 & 2 & 0 \\
\hline EMI/EMC & 0 & 0 & 2 \\
\hline TOTAL & 16 & 17 & 17 \\
\hline
\end{tabular}

Weightage: 0-Undesirable, 1-Desirable, 2-Most Desirable

Although there is an equal score of option (b) \& (c) we choose the option (c) due to EMI/EMC issues [4] with the electric motor and the sensors and force balances that will be attached on the prototype for testing. A Rotary Hydraulic Actuator which incorporates many quality features including precision ball bearings to provide shaft support, externally removable gland for ease of seal replacement and cylinders honed to a 10 micro inch finish to ensure long seal life giving the required torque specifications at feasible pressure values is selected.

\subsection{Bearings}

The selection of bearings and sizing the model according to the specifications is of importance in order to balance the forces and the moments. The classification of bearings can be seen as below [5]:

Table 3: Characteristics table for choosing Bearings

\begin{tabular}{|c|c|c|c|c|c|}
\hline $\begin{array}{l}\text { Bearing } \\
\text { Type }\end{array}$ & $\begin{array}{l}\text { Radia } \\
\text { l Load }\end{array}$ & $\begin{array}{l}\text { Axial } \\
\text { Load }\end{array}$ & Accuracy & $\begin{array}{l}\text { Low } \\
\text { Noise }\end{array}$ & $\begin{array}{l}\text { Low } \\
\text { Frictio } \\
n\end{array}$ \\
\hline $\begin{array}{l}\text { Deep } \\
\text { Groove } \\
\text { Ball } \\
\text { Bearing } \\
\text { s }\end{array}$ & Good & $\begin{array}{l}\text { Nor } \\
\text { mal }\end{array}$ & Normal & $\begin{array}{l}\text { Very } \\
\text { Good }\end{array}$ & $\begin{array}{l}\text { Very } \\
\text { Good }\end{array}$ \\
\hline $\begin{array}{l}\text { Crosse } \\
d \text { Roller } \\
\text { Bearing } \\
s\end{array}$ & $\begin{array}{l}\text { Very } \\
\text { Good }\end{array}$ & $\begin{array}{l}\text { Very } \\
\text { Good }\end{array}$ & Good & Good & $\begin{array}{l}\text { Very } \\
\text { Good }\end{array}$ \\
\hline $\begin{array}{l}\text { Cylindr } \\
\text { ical } \\
\text { roller } \\
\text { bearing } \\
\text { s }\end{array}$ & $\begin{array}{l}\text { Very } \\
\text { Good }\end{array}$ & Good & Good & $\begin{array}{l}\text { Suffi } \\
\text { cient }\end{array}$ & Good \\
\hline $\begin{array}{l}\text { Taper } \\
\text { Roller } \\
\text { Bearing } \\
\text { s }\end{array}$ & $\begin{array}{l}\text { Very } \\
\text { Good }\end{array}$ & $\begin{array}{l}\text { Very } \\
\text { Good }\end{array}$ & $\begin{array}{l}\text { Sufficien } \\
\mathrm{t}\end{array}$ & Good & Good \\
\hline $\begin{array}{l}\text { Spheric } \\
\text { al } \\
\text { Roller } \\
\text { Bearing } \\
\text { s }\end{array}$ & $\begin{array}{l}\text { Very } \\
\text { Good }\end{array}$ & Good & $\begin{array}{l}\text { Unsuitabl } \\
\text { e }\end{array}$ & $\begin{array}{l}\text { Suffi } \\
\text { cient }\end{array}$ & Good \\
\hline
\end{tabular}

From the above table, choosing crossed roller bearings since it is good with respect to all the parameters and is suitable for our application. These bearings will be extremely critical in the application to take the entire thrust load. In the CrossRoller Ring, cylindrical rollers are arranged crosswise, with each roller perpendicular to the adjacent roller, in a $90^{\circ} \mathrm{V}$ groove, separated from each other by a spacer retainer. This design allows just one bearing to receive loads in all 
directions including, radial, axial and moment loads. Since the Cross-Roller Ring achieves high rigidity despite the minimum possible dimensions of the inner and outer rings, it is optimal for applications such as joints and swivelling units of industrial robots, swivelling tables of machining centres etc. [6]. Crossed roller bearing was chosen for the assembly in order to fix one end of the assembly (transfers the thrust forces to the bottom or to the whole assembly) and the other end fixed to the spindle such that it is free to rotate and provide the desired angular motion. To support these bearings we use radial ball bearings on the other end. Crossed Roller bearings and radial ball bearings are preloaded during manufacturing itself, pre-load values for various rigidity levels are available in catalogue, and no adjustment is possible during assembly unlike angular contact bearings.

\subsection{Load Calculations \& Model Generation}

One important standard part extremely critical in the application because of the high speed, high temperature flow region is a seal ( to avoid fluid leakage in environment and from drying the bearings out of lubrication), U-Cup type of seal has a maximum pressure range up to $40 \mathrm{MPa}$ and would be suitable for the design. Other non-standard part used is the flange placed so that all the cables from prototype sensors and force balances can be taken out from this flange out to the main console for result evaluation. Standard bolts selected according to the stress analysis on the assembly.
The assembly was then analyzed for loads \& moments acting on center of axis of the roll drive. Since the forces are non-coplanar, vector mechanics is used to solve the forces and moments in the three planes and a resultant used to calculate the maximum value on the sting. The sting is taken into consideration and loads and moments applied since it is the rotating critical member of the assembly. Reactions on the points where the bearings are placed are calculated using simple engineering mechanics. Of the three planes yaw \& pitch planes are considered for force calculations, and making shear force \& bending moment diagrams for each plane [7]. Now the forces and moments on each point on the two planes are summed up using vector mechanics. With the shear forces and bending moments now combined at each point on the spindle, weakest section of the member is taken and designed for failure.

With the load ratings of the bearings from respective bearing catalogs, Basic life and Safety factor of the bearings is calculated for optimum performance of the bearings without failure during operation. The CAD model was designed using SEIMENS PLM software NX 7.5. The cross section of the complete assembly can be seen as below with the details of the various parts.

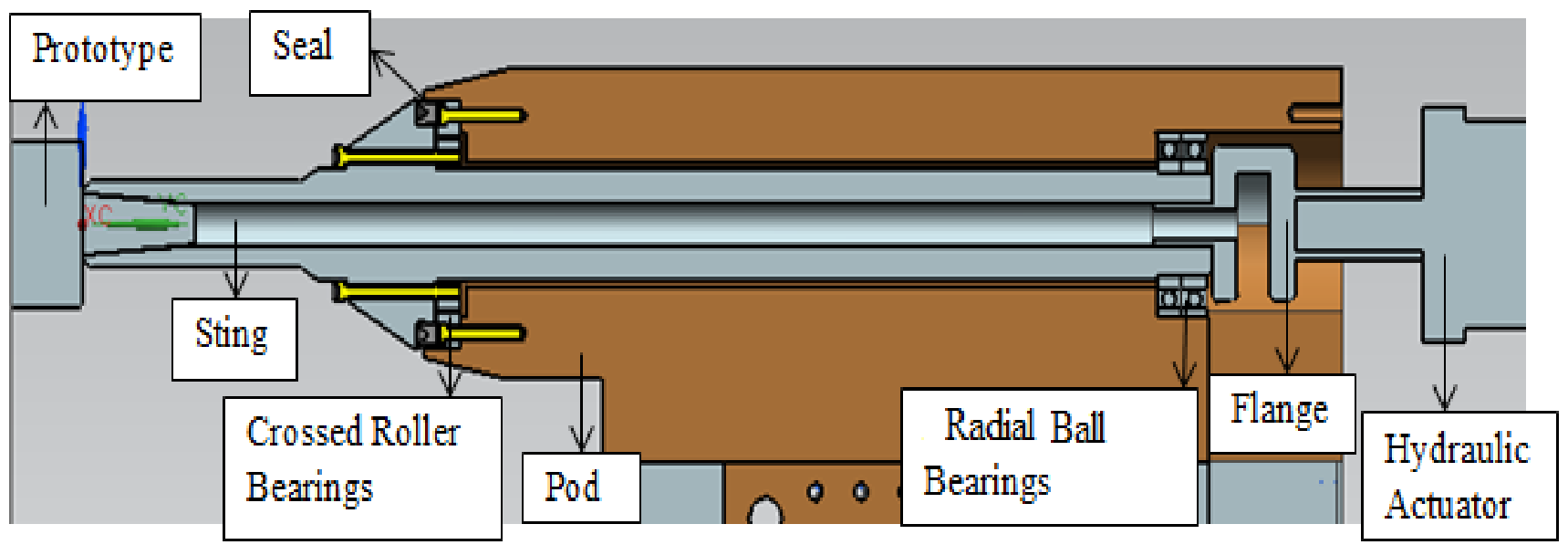

Fig 1: Cut sectional view of the Assembly

\subsection{Feedback Devices}

In order to determine the true position of the output shaft of the electrohydraulic drive, a position sensor is required. There are several types of position sensors available and each has its own merit and demerits [2]. They can be listed as below:
Table 4: Characteristics table for choosing Position Sensor

\begin{tabular}{|l|l|l|l|}
\hline Description & Resolver & $\begin{array}{l}\text { Optical } \\
\text { Encoder }\end{array}$ & $\begin{array}{l}\text { Rotary } \\
\text { Potentiomet } \\
\text { er }\end{array}$ \\
\hline Accuracy & High & High & Moderate \\
\hline Reliability & Very High & High & Moderate \\
\hline Availability & All Sizes & All Sizes & All Sizes \\
\hline Cost & High & Moderate & low \\
\hline
\end{tabular}


Principal selection criteria for selection of Position sensors are the accuracy requirements. Once the accuracy requirements are established the type of position sensor is selected based on ease of operation and cost. Thus, choosing Absolute encoders with hollow shaft mounting having number of turns of 24 bits having an SSI interface.

\section{HYDRAULIC SERVO SYSTEM}

A typical hydraulic servo system will have the following sub systems and can be named as below:

1) Hydraulic Power Supply

2) Servo Valve

3) Hydraulic Actuator

4) Encoder

5) Servo Controller

From the above mentioned sub systems, hydraulic actuator and encoder has already been discussed. The block diagram to explain the system can be seen below:

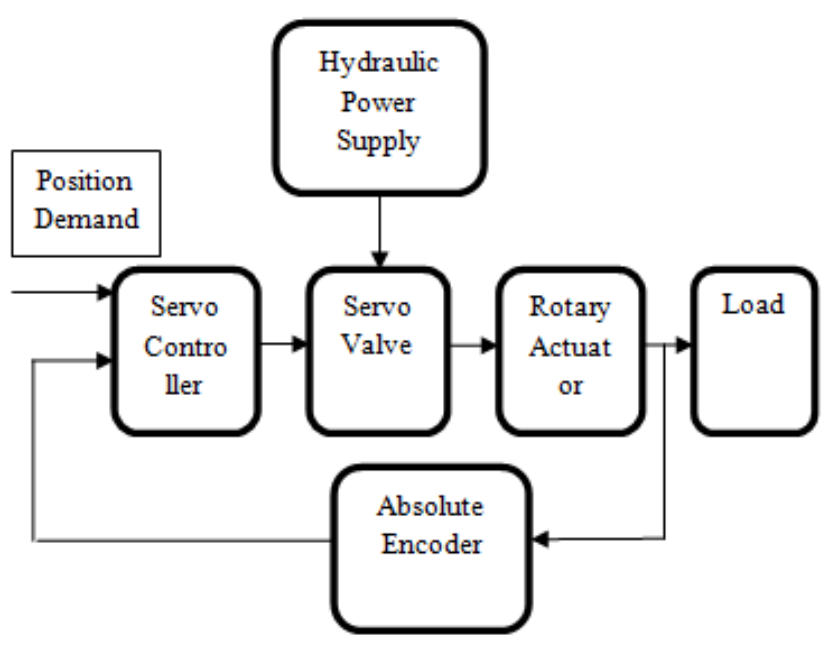

Fig 2: Block diagram of a position controlled Hydraulic Servo system

\subsection{Servo Valve}

There are two most important parameters on which the selection \& sizing of a servo valves [8] depends:

(a) Flow Requirement

- Specified or Desired Actuator Speed

- Limits by Pump flow

(b) Dynamic performance

- Acceleration

- Cycle time

- Accuracy

The electro-hydraulic flow control valve acts as a high gain electrical to hydraulic transducer, the input to which is an electrical voltage or current, and the output a variable flow of oil. The vast majority of flow control servo valves in existence employ a double flapper nozzle pilot stage and a single spool boost stage. A stiff feedback spring is generally used to provide feedback from the boost stage to the pilot. These types of servo valves tend to be difficult to manufacture and expensive. A less conventional, less costly type of flow control servo valve utilizes a two-spool boost stage and a flapper nozzle pressure control pilot. Because a feedback wire between the nozzle flapper pilot and the boost stage is not needed, assembly is simplified [1]. In order to size a servo valve its flow capacity should be calculated with the actuator specifications so that it is not oversized or undersized thereby reducing the system accuracy. An excel sheet is made on these lines to size the servo valve whose rated flow is estimated.

The servo valve with the complete system to produce a roll motion can be seen as in the Simulink model: 


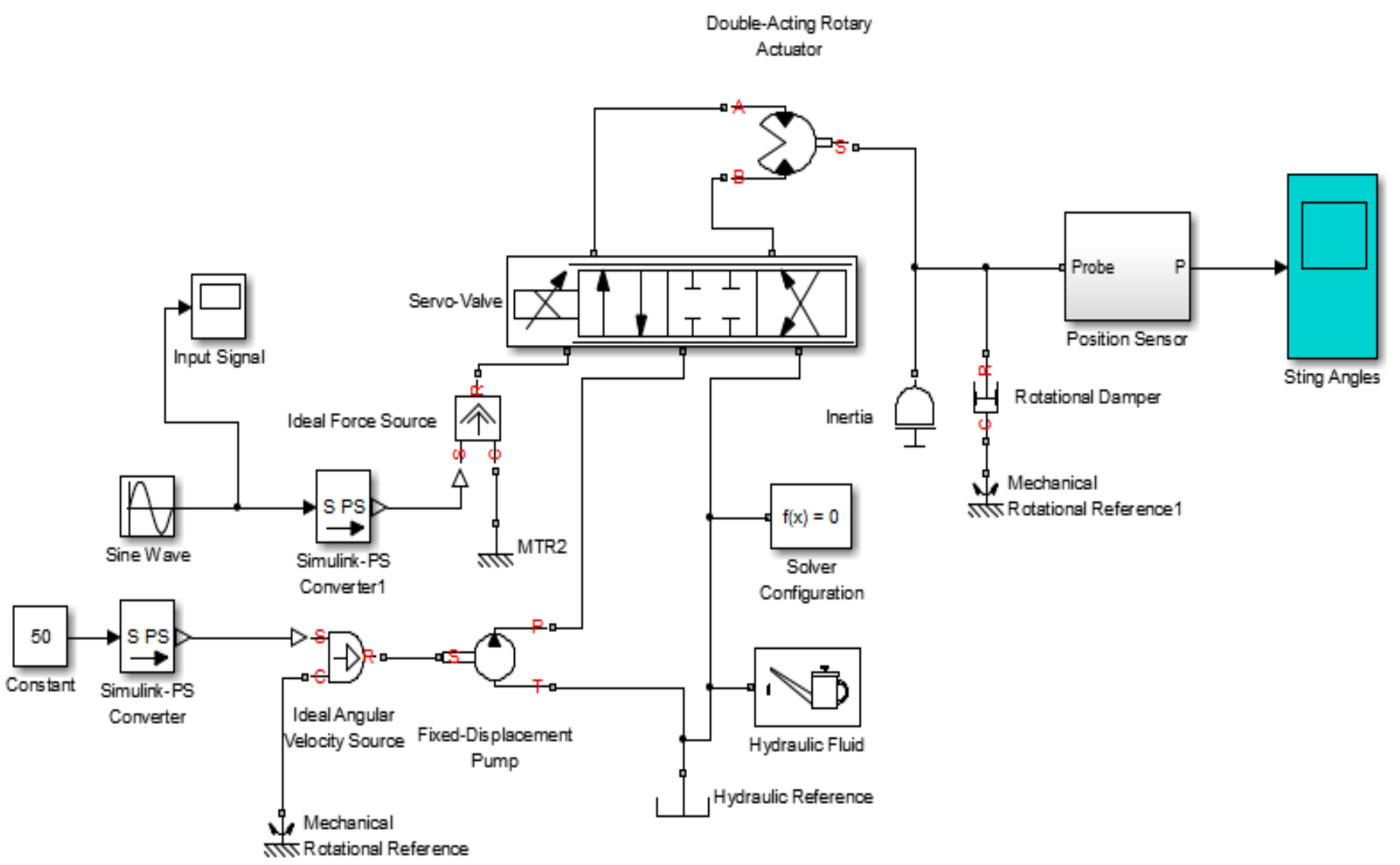

Fig 3: Simulink model of the Electrohydraulic Roll drive

The Simulink model is a design of the servo valve with the pump, motor and the hydraulic fluid used in the system. A position sensor or encoder detects the position of the Sting.

A Simulink model prepared using a servo valve with the specifications from calculations and assumptions is as seen below: The graph shows the output angles or the motion profile of the rotary actuator:

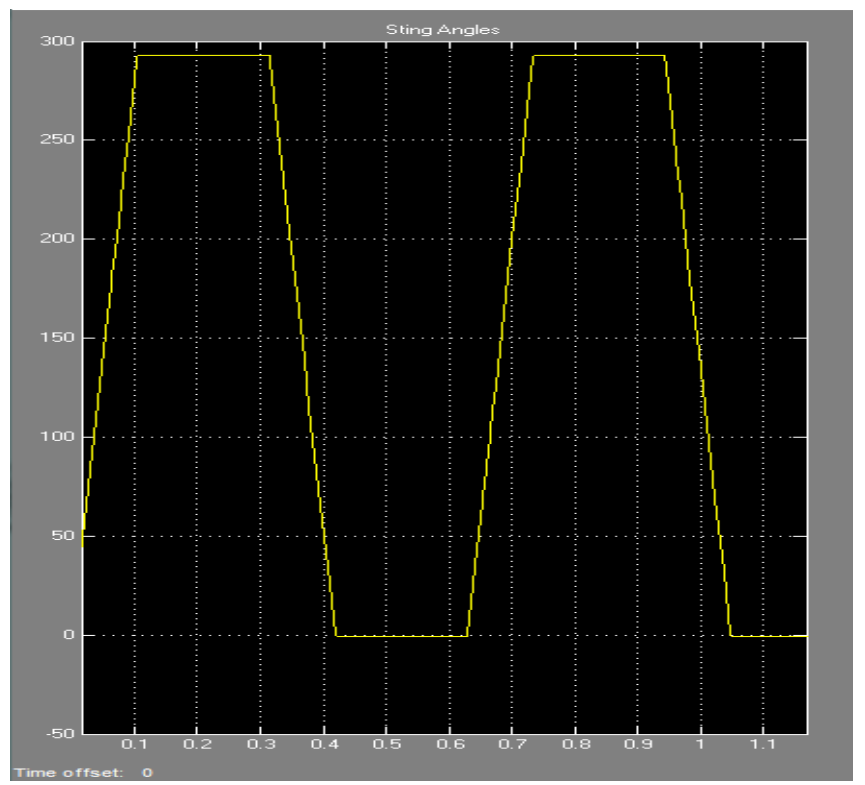

Fig 4: Angular displacement of rotary actuator
The above motion profile gives $280^{\circ}$ of rotation in the stipulated time, thus achieving the desired motion. The hydraulic forces acting on the ports of the servo valve can be as seen below:

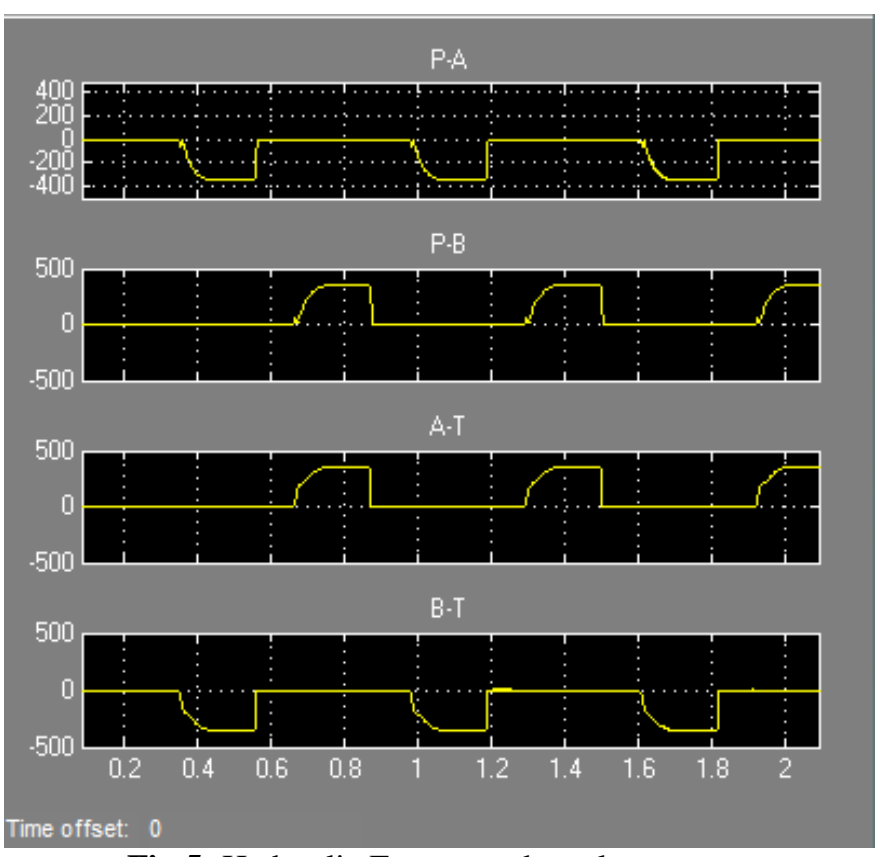

Fig 5: Hydraulic Forces on the valve ports. 
Thus the system operates typically with the desired angular motion and the forces under permissible value. Therefore the designed system follows a procedure that can be used to design various such sub systems in robotic analysis and research in order to achieve the desired motion.

\section{CONCLUSION}

1) This paper provides details of the criteria to be studied during the selection of various standard components to design an electro hydraulic system with the load conditions and accuracy requirements.

2) The parameters to be considered for choosing an electric or hydraulic drive are also summarised and the block diagram for the complete position control of the system is listed.

3) The paper includes the mathematical model of the system in SIMULINK using MATLAB with a servo valve for the controlled roll motion as well as the output graphs of the desired angular position.

\section{ACKNOWLEDGEMENTS}

We are highly grateful to Prof. Sangeeta Bansode, K.J. Somaiya College of Engineering and Mr. Arun Ramchandani \& Mr. Mahesh Verma, of HEIC, Larsen \& Toubro Ltd, Powai for giving the opportunity to carry out our project and we acknowledge their help in reviewing the Paper. We would like to express our gratitude to other faculty members of Mechanical Engineering Department of KJSCE, family and friends for providing academic inputs, guidance and encouragement throughout this period.

\section{REFERENCES}

[1]. Vijaya Sagar Tenali, Simulation of Electro-hydraulic Servo Actuator, masters diss., National Institute of Technology, Rourkela, India, 2007.

[2]. Abhishek Kumar, Anoop Kumar Srivastava, K Prakasha, and N Viswanatha, Design and Development of an Electromechanical Drive for Spacecraft Mechanisms- A Systematic Approach, 9th National Symposium and Exhibition on Aerospace and Related Mechanisms (ARMS 2015), 2015.

[3]. Jose L. Salmerona and Florentin Smarandache, Redesigning Decision Matrix Method with an indeterminacy-based inference process, Pablo de Olavide University at Seville (Spain), 2007.

[4]. B. Archambeault, O.M. Ramahi, C. Brench, EMI/EMC Computational Modeling Handbook, Second Edition, Kluwer Academic, 2001

[5]. Xiaofan Xie, Comparison of Bearings --- For the Bearing Choosing of High-speed Spindle Design, 2003.

[6]. Naoki Yamaguchi, Motion System Design, NB Corp. of America Hanover Park, III. 2010.

[7]. S. Ramamrutham \& R Narayanan, Strength of materials, Dhanpat Rai, 2008, 160-282.

[8]. Neal Hanson, "Selecting Proportional Valves And High Response Valves”, Rexroth Bosch Group, 2006. 